\title{
Use of sweet 'Pêra' peel as an adsorbent in the treatment of textile effluents
}

\author{
Ketyla K. R. do Nascimento ${ }^{1}$, Fernando F. Vieira ${ }^{1}$, Marcello M. de Almeida ${ }^{1}$, Josué da S. Buriti²,
} Aldre J. M. Barros ${ }^{3} \&$ Rodrigo J. de Oliveira ${ }^{4}$

${ }^{1}$ Universidade Estadual da Paraíba/Departamento de Engenharia Sanitária e Ambiental. Campina Grande, PB, Brasil. E-mail: ketyllakarlla@hotmail.com
(Corresponding author) - ORCID: 0000-0001-6751-5744; fernando@uepb.edu.br - ORCID: 0000-0002-1823-6236; marcello_maia2000@yahoo.com.br -
ORCID: 0000-0001-7889-126X
${ }^{2}$ Universidade Federal de Campina Grande/Unidade Acadêmica de Engenharia de Materiais. Campina Grande, PB, Brasil. E-mail: josueburiti@gmail.com
- ORCID: 0000-0003-3207-2781
${ }^{3}$ Universidade Federal de Campina Grande/Unidade Acadêmica de Engenharia de Biotecnologia e Bioprocessos. Campina Grande, PB, Brasil. E-mail:
aldrejmb@ufcg.edu.br - ORCID: 0000-0001-6861-1228
${ }^{4}$ Universidade Estadual da Paraíba/Departamento de Química. Campina Grande, PB, Brasil.E-mail: rodrigo@cct.uepb.edu.br-ORCID:0000-0002-8753-2661

\begin{abstract}
The disposal of industrial wastewater into aquatic bodies without proper treatment can cause severe damage to the environment and human health. The objective of this study was to perform the drying of the sweet orange (Citrus sinensis L. Osbeck) peel cultivar Pêra and evaluate the viability of its use as biosorbent in the removal of a direct dye. Drying was carried out in an oven with air circulation at temperatures of 60 and $80^{\circ} \mathrm{C}$. The mathematical models of Page, Henderson and Pabis, Logarithmic, Midilli and Two-term exponential were fitted to the moisture data as a function of time. The material was characterized by scanning electron microscopy, point of zero charge, and infrared spectroscopy. In the adsorption study, a complete $2^{4}$ factorial design was used to analyze the influence of mass, initial concentration, solution $\mathrm{pH}$ and contact time on adsorbed quantity (qt) and removal percentage of the dye (R\%). In the drying, the two-term exponential model fitted best to the experimental data. The characterization of the material indicated that the adsorbent has zero charge point of 3.5 and porous structure, and the infrared analysis indicated the presence of carboxylic and hydroxyl groups. In the adsorption, the adsorbed quantity of the dye increased under conditions of lower $\mathrm{pH}$ and biosorbent mass and higher initial concentration and contact time. The removal percentage of dye increases with higher biosorbent mass. The biosorbent used is a promising waste for the adsorption of the burgundy-16 dye.
\end{abstract}

Key words: dyes, experimental design, wastes

\section{Aproveitamento da casca de laranja Pêra como adsorvente no tratamento de efluentes têxteis}

RESUMO: O lançamento de águas residuárias industriais em corpos aquáticos, sem o devido tratamento, pode causar danos severos ao meio ambiente e à saúde humana. O objetivo deste estudo foi realizar a secagem da casca de laranja cultivar Pêra (Citrus sinensis L. Osbeck) e avaliar a viabilidade do seu uso como biossorvente para remoção de um corante direto. A secagem foi realizada em estufa com circulação de ar nas temperaturas de 60 e $80^{\circ} \mathrm{C}$. Os dados de umidade em função do tempo foram ajustados aos modelos matemáticos de Page, Henderson e Pabis, Logarítmico, Midilli e exponencial de dois termos. A caracterização do material foi realizada a partir da microscopia eletrônica de varredura, do ponto de carga zero, e da espectroscopia na região do infravermelho. No estudo da adsorção realizou-se um planejamento fatorial $2^{4}$ completo, analisando-se a influência da massa, concentração inicial, $\mathrm{pH}$ da solução e tempo de contato, na quantidade adsorvida (qt) e no percentual de remoção do corante $(\mathrm{R} \%)$. Na secagem, o modelo exponencial de dois termos apresentou melhor ajuste aos dados experimentais. A caracterização do material apontou que o adsorvente apresenta ponto de carga zero de 3,5 e estrutura porosa, e as análises de infravermelho indicaram a presença de grupos carboxílicos e hidroxilas. $\mathrm{Na}$ adsorção, a quantidade adsorvida do corante aumentou em condições de menor pH e massa de biossorvente, maior concentração inicial e tempo de contato. O percentual de remoção do corante aumenta com maior massa de biossorvente. O biossorvente utilizado é um resíduo promissor para a adsorção do corante bordô-16.

Palavras-chave: corantes, planejamento experimental, rejeito 


\section{INTRODUCTION}

The disposal of industrial wastewater into water bodies, without proper treatment, can cause severe damage to the environment and human health (Mostafa, 2015; Santos et al., 2017). Textile industries are present in most countries due to a human need for clothing and varied utility uses. In Brazil, they have a great economic importance (ABIT, 2013).

Effluents with high concentration of dye restrict the penetration of solar radiation, compromising the photosynthetic activity in water systems and reducing the level of oxygenation of the aquatic environment (Holanda et al., 2012).

Among the wastewater treatment technologies adequate for color removal, adsorption is shown to be a superior alternative to other techniques in terms of efficiency, simplicity of projects and ease of operation (Barrios-Ziolo et al., 2015).

Due to the high cost of activated charcoal, new studies have sought alternative biosorbents, such as agroindustrial wastes, because they are abundant, biodegradable, inexpensive and efficient in the adsorption of dyes (Holanda et al., 2012; Nascimento et al., 2014; Santhi et al., 2016).

The uses of agricultural by-products demonstrate that such materials can be used for the adsorption of various pollutants, including dyes. Orange peel is a by-product of the production of juices, being the agroindustrial waste obtained in largest quantity in Brazil (Rehman et al., 2012; Fiorentin et al., 2015).

This study aimed to perform the drying of orange peel and the modeling of the drying data, as well as to evaluate this agroindustrial waste as a biosorbent, in order to reduce the inadequate disposal of this waste and using it in the removal of the direct burgundy-16 dye from the Tupy brand, present in aqueous solutions, widely used in small-scale dyeing shops.

\section{Material ANd Methods}

The raw material used in the experimental tests was the peel of the sweet orange (Citrus sinensis L. Osbeck) cultivar 'Pêra' obtained in the central market of the city of Campina Grande, PB, Brazil.

The study was carried out in the Laboratory of Research on Environmental Sciences (LAPECA), located at $7^{\circ} 20^{\prime} \mathrm{S}$ and $35^{\circ}$ 91' $\mathrm{W}$ and in the Experimental Station of Biological Treatment of Sanitary Sewage (EXTRABES), located at $7^{\circ} 24^{\prime}$ S, 35 $88^{\prime}$ W and altitude of $551 \mathrm{~m}$, both belonging to the Centro de Ciência e Tecnologia (CCT) da Universidade Estadual da Paraíba (UEPB), located in the city of Campina Grande, PB, Brazil.

The oranges were initially washed with public-supply water and subsequently with distilled water. They were then cut into four parts in the longitudinal direction of the fruit. The pulp was removed and the orange peels were cut into approximately equal-sized pieces of $1.0 \mathrm{~cm}^{2}$.

The initial moisture, on dry basis, of the orange peels, was determined by the oven method at $105{ }^{\circ} \mathrm{C}$. The tests were conducted in triplicate, in which three $10 \mathrm{~g}$ samples were weighed on a Marconi AL500C analytical scale and dried in a Marconi MA 035/3IN250 oven.

For the construction of the drying curves, the weight variation of the samples over time was monitored during the initial $4.5 \mathrm{~h}$. The monitoring was performed every $5 \mathrm{~min}$ in the first hour, every $10 \mathrm{~min}$ in the next $2 \mathrm{~h}$, and then every 15 min until completing the $4.5 \mathrm{~h}$ of monitoring.

The weighings were performed on a Marconi AL500C analytical scale. The drying process was performed in triplicate, in a Marconi MA 035/3IN250 oven with forced air circulation, with speed of $1.5 \mathrm{~m} \mathrm{~s}^{-1}$, at temperatures of 60 and $80^{\circ} \mathrm{C}$.

After the monitoring period, the samples remained in the oven until the end of the $24 \mathrm{~h}$, until reaching constant dry mass. To predict the drying behavior, the mathematical models of Page, Henderson \& Pabis, Logarithmic, Midilli and Two-term exponential, represented by the Eqs. 1, 2, 3, 4 and 5 , respectively, were fitted to these data:

$$
\begin{gathered}
M R=\exp ^{\left(-k t^{\mathrm{n}}\right)} \\
M R=a \exp ^{(-\mathrm{kt})} \\
\mathrm{MR}=\mathrm{a} \exp ^{(-\mathrm{kt})}+\mathrm{c} \\
\mathrm{MR}=\mathrm{a} \exp ^{\left(-\mathrm{kt}^{\mathrm{n}}\right)}+\mathrm{bt} \\
\mathrm{MR}=\mathrm{a} \exp ^{(-\mathrm{kt})}+(1-\mathrm{a}) \exp ^{(-\mathrm{kta})}
\end{gathered}
$$

where:

MR - moisture ratio of the product, dimensionless;

$\mathrm{t}$ - drying time, min;

$\mathrm{k} \quad$ - drying constant, $\mathrm{min}^{-1}$;

$\mathrm{n}$ - coefficient of the model, dimensionless;

a - coefficient of the model, dimensionless;

b - coefficient of the model, $\mathrm{min}^{-1}$; and,

c - coefficient of the model, dimensionless.

The moisture ratio (MR), during the drying at different temperatures, was calculated using Eq. 6:

$$
\mathrm{MR}=\frac{\mathrm{M}-\mathrm{M}_{\mathrm{e}}}{\mathrm{M}_{\mathrm{I}}-\mathrm{M}_{\mathrm{e}}}
$$

where:

M - moisture content of the product, g;

$M_{I}$ - initial moisture content of the product, g; and,

$\mathrm{M}_{\mathrm{e}}$ - equilibrium moisture content of the product, $\mathrm{g}$.

To fit the mathematical models to the experimental drying data, nonlinear regression analysis was performed using the Gauss-Newton method, through the Minitab statistical software.

At the end of each drying experiment, the dried material was crushed and after this process, the crushed material was separated using Bertel Mesh 8 sieves, in order to obtain a material with particle size smaller than $2.36 \mathrm{~mm}$.

For the adsorption tests, as well as for biosorbent characterization, the material obtained after drying at $80{ }^{\circ} \mathrm{C}$ was used based on preliminary tests. 
The biosorbent was characterized by determining the point of zero charge (PZC) according to the methodology proposed by Boas et al. (2012), analysis by scanning electron microscopy (SEM) and Fourier transform infrared spectrum (FTIR).

Material morphology and quantitative analysis of the chemical composition of the samples were analyzed in a Phenom PRO X scanning electron microscope, with up to $45000 \mathrm{x}$ magnification, depth of focus of $1 \mathrm{~mm}$, resolution of $30 \mathrm{~nm}$, and tension of $15 \mathrm{kV}$, low vacuum and varied pressure ( 1 to $270 \mathrm{~Pa}$ ). The images were magnified by 20 and 2000 times.

To determine the functional groups present in the orange peel, the Fourier transform Infrared spectroscopy technique was used in the Perkin Elmer Spectrum 400 spectrophotometer. The spectra were obtained in the absorption region between 4000 and $600 \mathrm{~cm}^{-1}$, with a resolution of $4 \mathrm{~cm}^{-1}$.

As adsorbate, a solution of the direct burgundy-16 dye, from Tupy brand, was used. A $2000 \mathrm{mg} \mathrm{L}^{-1}$ stock solution was prepared and used for the dilutions to obtain the work solutions.

Dye concentration in the sample was determined by molecular absorption spectrophotometry in a BEL SP 2000 UV spectrophotometer.

Initially, the wavelength at which the compound to be quantified absorbs the maximum radiation was determined by scanning the spectrum within the range from 400 to $700 \mathrm{~nm}$, and $520 \mathrm{~nm}$ was the wavelength that showed the highest absorption. The calibration curve was then constructed using the dye solutions under study, with different concentrations, within a range from 0 to $200 \mathrm{mg} \mathrm{L}^{-1}$.

In order to optimize the adsorption process, a complete $2^{4}$ factorial design with three repetitions at the central point was applied to analyze the influence of four factors: mass, initial concentration, $\mathrm{pH}$ solution and contact time.

Table 1 presents the actual and coded values of the factors applied in the experimental design.

The quantity of dye adsorbed (qt) and the removal percentage $\left(\mathrm{R}_{\%}\right)$ were calculated using Eqs. 7 and 8, respectively:

$$
\begin{aligned}
q t & =\frac{\left(C_{I}-C_{F}\right) V}{M} \\
R_{\%} & =\frac{\left(C_{I}-C_{F}\right)}{C_{I}} 100
\end{aligned}
$$

where:

$\mathrm{C}_{\mathrm{I}} \quad$ - initial dye concentration, $\mathrm{mg} \mathrm{L}^{-1}$;

$\mathrm{C}_{\mathrm{F}}$ - dye concentration at the time, $\mathrm{mg} \mathrm{L}^{-1}$;

$\mathrm{M}$ - mass of biosorbent (orange peel); and,

$\mathrm{V}$ - volume of dye solution, L.

Table 1. Actual and coded values of the factors applied in the experimental design

\begin{tabular}{lccc}
\hline \multirow{2}{*}{ Factor } & \multicolumn{3}{c|}{ Level } \\
\cline { 2 - 4 } & -1 & $\mathbf{0}$ & +1 \\
Mass of the orange peel $(\mathrm{g})$ & 0.2 & 0.3 & 0.4 \\
Dye concentration $\left(\mathrm{mg} \mathrm{L}^{-1}\right)$ & 100 & 150 & 200 \\
$\mathrm{pH}$ & 4 & 5 & 6 \\
Contact time (min) & 20 & 30 & 40 \\
\hline
\end{tabular}

The influences of the variables were evaluated using the statistical analysis with Minitab software.

\section{Results ANd Discussion}

It was observed that, as expected, the higher the drying air temperature, the greater the reduction of moisture in the initial phase of the process (Figures $1 \mathrm{~A}$ and $\mathrm{B}$ ). This behavior has also been reported by other authors (Tamer et al., 2016; Corrêa Filho et al., 2018).

As shown in Figures 1A and B, the two-term exponential model fitted to the experimental data, at both temperatures evaluated in this study showed higher values of coefficient of determination $\left(\mathrm{R}^{2}\right)$ and $\mathrm{F}$ value and lower value of estimated mean error - SE, corroborating the good fit of the model to the experimental data (Table 2).

With the great diversity in the studies on the drying of residues, fruits, leaves and seeds reported in the literature, different models have shown satisfactory fits for the modeling of experimental data.

Although all models fitted well, with coefficients of determination above 0.99 and high $\mathrm{F}$ value, the Henderson \& Pabis and logarithmic models, in the predicted values of $M_{I}$, showed values greater than 1 , which are not acceptable. This behavior was also reported by Fiorentin et al. (2012) with the two-term exponential model, in the drying of orange bagasse.

According to Barros Neto et al. (2001), the model can be considered predictive if the $\mathrm{F}$ value is greater than 10 , verified for both temperatures, corroborating the good fit of the model,

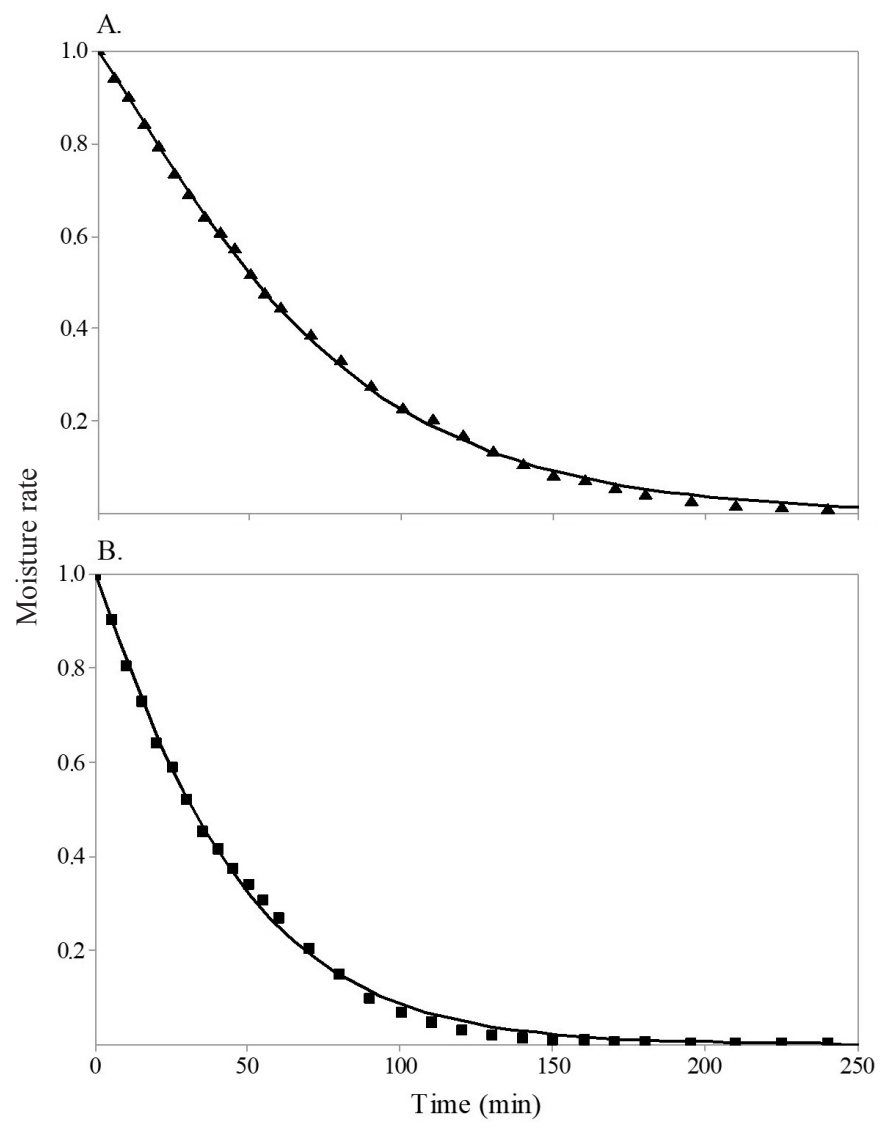

Figure 1. Moisture rate (MR) of orange peels as function of drying time at $60{ }^{\circ} \mathrm{C}(\mathrm{A})$ and $80{ }^{\circ} \mathrm{C}(\mathrm{B})$ 
Table 2. Comparison of statistical parameters of the drying models

\begin{tabular}{|c|c|c|c|c|c|c|c|c|c|c|c|}
\hline $\mathrm{T}\left({ }^{\circ} \mathbf{C}\right)$ & Model & $M_{I}$ & $M_{F}$ & $k\left(\min ^{-1}\right)$ & a (-) & $n(-)$ & b $\left(\mathrm{min}^{-1}\right)$ & C & F value & SE & $\mathbf{R}^{2}$ \\
\hline \multirow{5}{*}{60} & Two-term Exp. & 1 & $1.88 \mathrm{E}-12$ & 0.019 & 1.662 & - & - & - & 4855.93 & 0.00994 & 0.999 \\
\hline & Page & 1 & 7.6E-15 & 0.007 & - & 1.147 & - & - & 4246.35 & 0.01067 & 0.999 \\
\hline & Midilli & 0.956 & 0.005 & 0.005 & 0.956 & 1.231 & 3.7E-06 & - & 2490.62 & 0.01042 & 0.999 \\
\hline & Logarithmic & 1.024 & 0.033 & 0.013 & 1.057 & - & - & 0.033 & 1439.56 & 0.01564 & 0.998 \\
\hline & Henderson \& Pabis & 1.037 & $3.67 \mathrm{E}-10$ & 0.015 & 1.037 & - & - & - & 1005.99 & 0.02139 & 0.996 \\
\hline \multirow{5}{*}{80} & Two-term Exp. & 1 & $5.81 \mathrm{E}-18$ & 0.027 & 1.597 & - & - & - & 2186.73 & 0.01348 & 0.998 \\
\hline & Page & 1 & $6.75 \mathrm{E}-21$ & 0.014 & - & 1.112 & - & - & 1894.91 & 0.01476 & 0.997 \\
\hline & Midilli & 0.918 & 0.0005 & 0.007 & 0.918 & 1.272 & $3.67 \mathrm{E}-07$ & - & 731.75 & 0.01717 & 0.996 \\
\hline & Logarithmic & 1.012 & 0.018 & 0.021 & 1.030 & - & - & 0.018 & 975.08 & 0.01717 & 0.996 \\
\hline & Henderson \& Pabis & 1.019 & $7.78 \mathrm{E}-15$ & 0.023 & 1.019 & - & - & - & 954.65 & 0.02001 & 0.995 \\
\hline
\end{tabular}

SE - Standard error; $M_{1}$ and $M_{F}$ - Initial and final moisture contents, respectively; $a, n, b, c$, respectively coefficient of the model

which was considered a statistically significant and predictive model at 0.05 confidence interval.

The graph of $\Delta \mathrm{pH}\left(\mathrm{pH}_{\text {Final }}-\mathrm{pH}_{\text {Initial }}\right)$ as a function of $\mathrm{pH}_{\text {Initial' }}$ for the biosorbent, is presented in Figure 2A, which shows that the point of zero charge $\left(\mathrm{pH}_{\mathrm{pzc}}\right)$ of the material is approximately 3.5. Guiza (2017) evaluated the point of zero charge of the orange peel and obtained $\mathrm{pH}_{\mathrm{pzc}}$ of 3.85 , and Nascimento et al. (2014) obtained $\mathrm{pH}_{\mathrm{pzc}}$ of 3.9.

According to Guiza (2017), in solutions with $\mathrm{pH}$ below the $\mathrm{pH}_{\text {pzc }}$, the surface of the material charged with $\mathrm{H}^{+}$ions favors the adsorption of dyes with anionic characteristic, and, in a solution with $\mathrm{pH}$ above the $\mathrm{pH}_{\mathrm{pzc}}$, the surface is charged with $\mathrm{OH}^{-}$ions, favoring the adsorption of cationic dyes.

The micrograph of the biosorbent made from orange peel can be observed in Figure 2B. It is observed that the material exhibited heterogeneous surface. Mafra et al. (2013) state that orange peel has porous and highly heterogeneous structure, characteristics that were also reported by Guiza (2017).

The FTIR spectrum of the biosorbent material can be observed in Figure 2C, where several absorption bands were identified, which indicate the presence of several functional groups in the material. The FTIR spectrum showed similar behavior to that observed by Khaled et al. (2009) and Mafra et al. (2013).

The extensive absorption of the band around $3350 \mathrm{~cm}^{-1}$ corresponds to the stretching vibrations of the $\mathrm{O}-\mathrm{H}$ groups, which may be related to the presence of the hydroxyl groups free of carboxylic acids, alcohols and phenols on the adsorbent surface or corresponds to O-H stretching vibrations of cellulose, pectin, absorbed water and lignin (Djilani et al., 2012; Cypriano et al., 2017).

Bands centered at $2900 \mathrm{~cm}^{-1}$ are attributed to the symmetrical and asymmetrical stretching vibrations of $\mathrm{CH}$ of aliphatic molecules. In turn, the bands close to $1750 \mathrm{~cm}^{-1}$ indicate stretching vibrations of the non-ionic carbonyl fraction of carboxylic acids and esters, as observed by Feng et al. (2010) and Djilani et al. (2012).

There are bands in the region of $1600 \mathrm{~cm}^{-1}$, which represented the axial deformation of the carboxylate ions, COO-, of the free carboxyl, that is, of the non-esterified carboxylic groups, as described by Gnanasambandam \& Proctor (2000).

The vibration of aliphatic acid groups at $1200 \mathrm{~cm}^{-1} \mathrm{can}$ be attributed to the deformation of $\mathrm{C}=\mathrm{O}$ groups and to the elongation of formation of $\mathrm{OH}$ groups of carboxylic acids
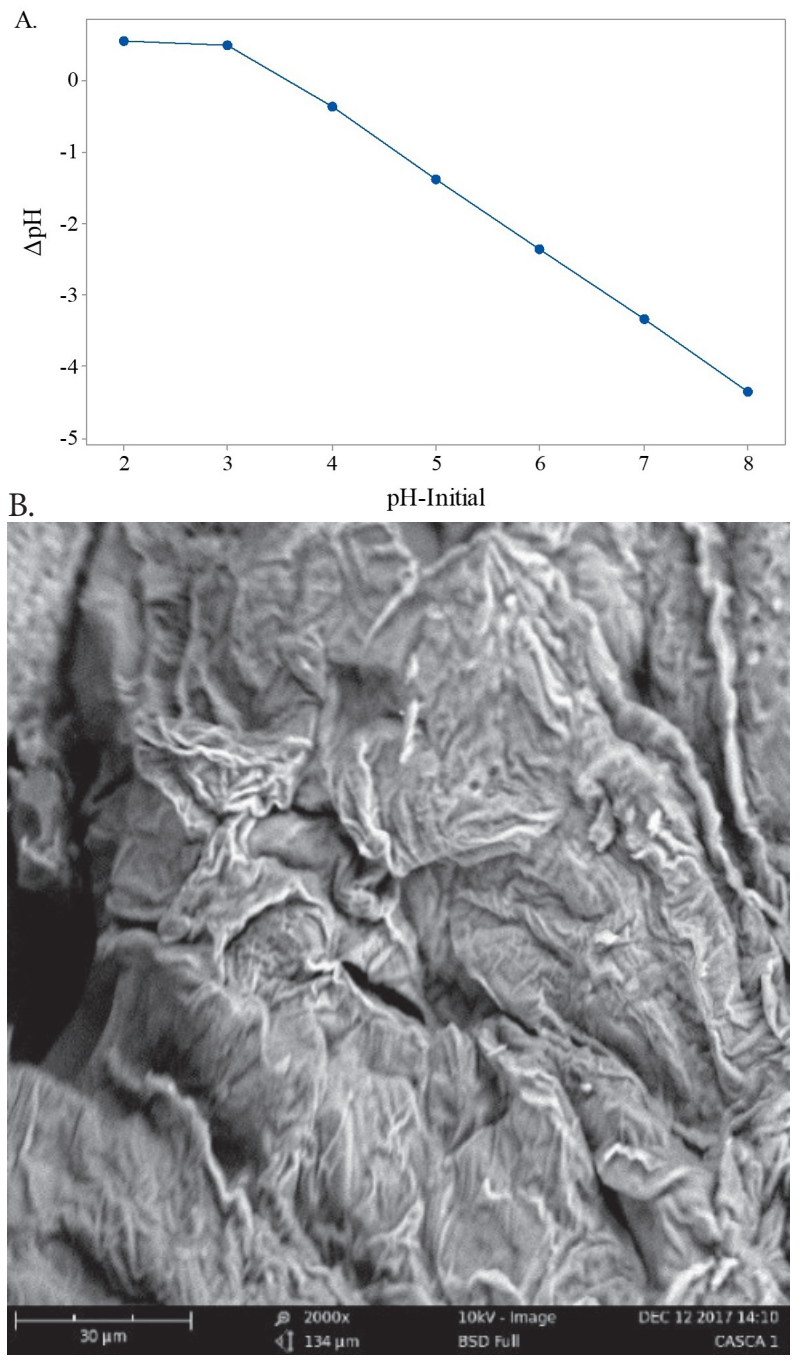

C.

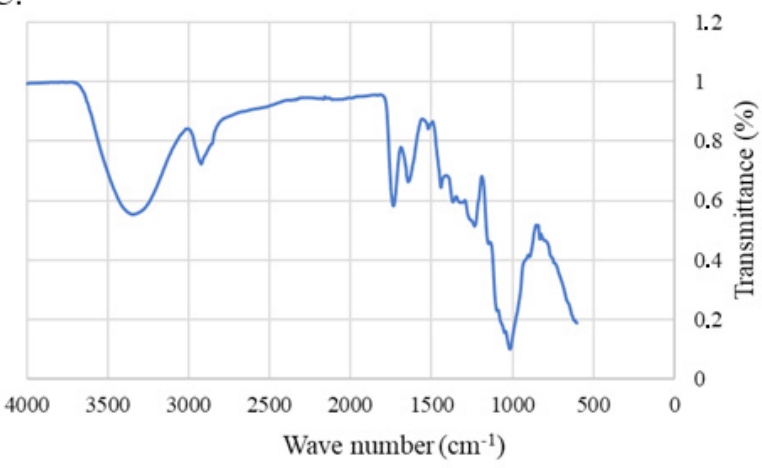

Figure 2. Graph of the point of zero charge - $\mathrm{pH}_{\mathrm{pzc}}(\mathrm{A})$, micrographs of the biosorbent material with $2000 x$ magnification (B) and Fourier transform infrared spectrum - FTIR (C) 
and phenols, as reported by Mafra et al. (2013) and Santos \& Morais (2015).

The Pareto charts, shown in Figure 3, show the influences of the factors on the qt (Figure $3 \mathrm{~A}$ ) and reduction percentage of the dye (Figure $3 \mathrm{~B}$ ), respectively.

The factors are statistically significant at $p \leq 0.05$ for adsorbed quantity of dye (qt). For the reduction of the dye, the initial concentration of the dye was not significant, while the contact time, mass of orange peels and $\mathrm{pH}$ solution were statistically significant at $\mathrm{p} \leq 0.05$.

The dye initial concentration had a positive effect on the qt, evidencing that, with the increase in the solution concentration, the quantity of adsorbed dye increased and such condition occurs due to the saturation of the dye solution, which facilitates the adsorption process.

According to Noreen et al. (2013), the initial dye concentration plays an important role, because it reduces the resistance to dye mass transfer between the solid and aqueous phases. The authors evaluated the removal of the black CL-B dye in peanut husk and observed similar behavior, in which increasing the concentration from 10 to $600 \mathrm{mg} \mathrm{L}^{-1}$ increased the adsorbed quantity from 22 to $48 \mathrm{mg} \mathrm{g}^{-1}$.

Safa \& Bhatti (2011) evaluated the adsorption of direct red-31 dye in rice husk and observed that, with the increase in the initial concentration, the adsorbent quantity increased from 11.19 to $65.56 \mathrm{mg} \mathrm{g}^{-1}$.

The increase of mass from 0.2 to $0.4 \mathrm{~g}$ had a negative effect on qt, decreasing $44.56 \%$ the adsorbed quantity, i.e., there is a sub-utilization of the biosorbent material.

A.

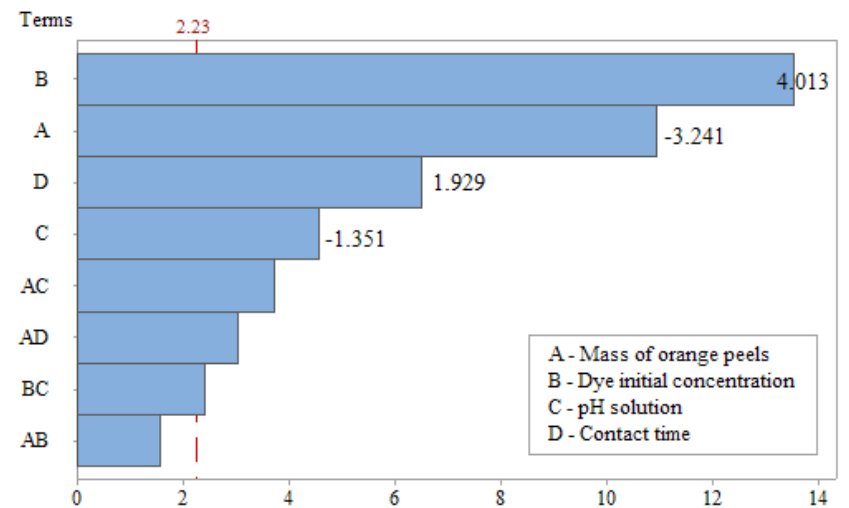

B.

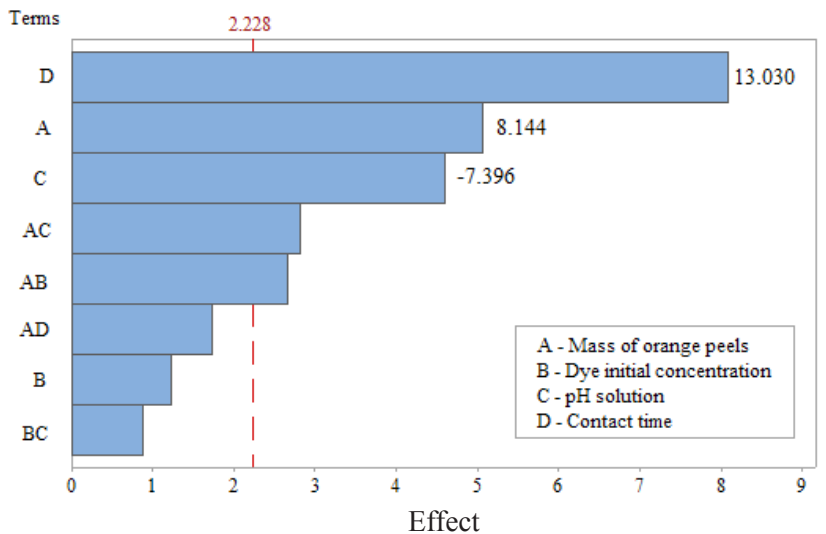

Figure 3. Pareto charts of the standardized effects for the adsorbed quantity - qt (A) and removal percentage - $\mathrm{R}_{\%}$ of dye as function of evaluated factors (B)
Nascimento et al. (2014) evaluated the adsorption of the reactive gray $\mathrm{BF}-2 \mathrm{R}$ dye in orange peel and obtained similar results, in which increasing the mass from 0.25 to $0.75 \mathrm{~g}$ led to a reduction of $50.7 \%$ in the adsorption capacity.

For the removal percentage of the dye, the mass of orange peels had a positive effect, indicating that the increment in the biosorbent mass increases the number of active sites in the medium, and consequently, it causes a greater reduction of the dye concentration.

Rehman et al. (2012) studied the removal of methylene blue dye with rice husk as biosorbent and observed a similar behavior, in which the biosorbent mass also had a positive effect.

The contact time had a positive effect on both responses evaluated; therefore, as the time of contact between the liquid phase and the solid phase increases, the adsorbed quantity and the percentage of dye removal increase.

Pavan et al. (2007) evaluated the removal of methylene blue dye using yellow passion fruit peel and mandarin peel and the variable time also had a positive effect on the percentage of dye removal.

The $\mathrm{pH}$ solution had a negative effect on both evaluated responses, indicating that, under conditions of higher concentration of $\mathrm{H}^{+}$ions, there is an increase in the adsorption capacity and removal percentage.

The $\mathrm{pH}$ is a factor of great importance in the study of the adsorption of dyes, because it affects the superficial charge of the biosorbent; thus, the change in solution $\mathrm{pH}$ affects the adsorption process through the dissociation of the functional groups at the active sites of the surface of the biosorbent. Asfaram et al. (2014) studied the adsorption of the direct red $12 \mathrm{~B}$ dye in garlic peel, varying the values from 2 to 10 , and observed that the adsorption capacity was elevated in solutions with lower $\mathrm{pH}$.

Table 3 presents the analysis of variance for both response variables evaluated.

It was observed that the models fitted well to the experimental data, showing highly expressive coefficients of determination, where more than $92 \%$ of the variations in the responses can be explained by the models.

According to Barros Neto et al. (2001), the model for the response qt can be considered statistically significant and predictive. For the response reduction, the value of the F test was higher than 1 , and the model was statistically significant at $\mathrm{p} \leq 0.05$.

The contour plots in Figure 4 show the influence of the variables dye initial concentration, mass orange peels and $\mathrm{pH}$ solution, at the fixed time of $40 \mathrm{~min}$, for the adsorbed quantity (qt) and removal percentage of dye (R\%).

It was observed that, for qt, the higher the mass of biosorbent, the lower the adsorbed quantity, evidencing the good potential of the biosorbent material, which had good adsorption capacity even in small quantities.

For the removal percentage of dye, it can be stated that the dye initial concentration was not a factor of great importance, and the orange peel mass was the main factor. Both responses evaluated were favored in acid medium, because higher values of qt and removal percentage of dye were observed at $\mathrm{pH}$ solution equal to 4 . 
Table 3. Analysis of variance for the factors mass of orange peels, dye initial concentration, pH solution and contact time for the adsorbed quantity (qt) and removal percentage (R\%) of dye

\begin{tabular}{|c|c|c|c|c|c|c|c|}
\hline Source of variation & Sum of squares & $\mathrm{DF}$ & Quadratic mean & $\mathbf{F}_{\text {(calculated) }}$ & $F_{\text {(tabulated) }}$ & F test & $\mathrm{R}^{2}$ \\
\hline \\
\hline Regression & 139.61 & 8 & 17.450 & 49.71 & 3.07 & 16.19 & 0.975 \\
\hline Residual & 3.51 & 10 & 0.351 & & & & \\
\hline Total & 143.12 & & & & & & \\
\hline \multicolumn{8}{|c|}{$\mathrm{R} \%$} \\
\hline Regression & 1372.68 & 8 & 171.58 & 16.51 & 3.07 & 5.37 & 0.929 \\
\hline Residual & 103.98 & 10 & 10.39 & & & & \\
\hline Total & 1476.65 & & & & & & \\
\hline
\end{tabular}

DF - Degrees of freedom
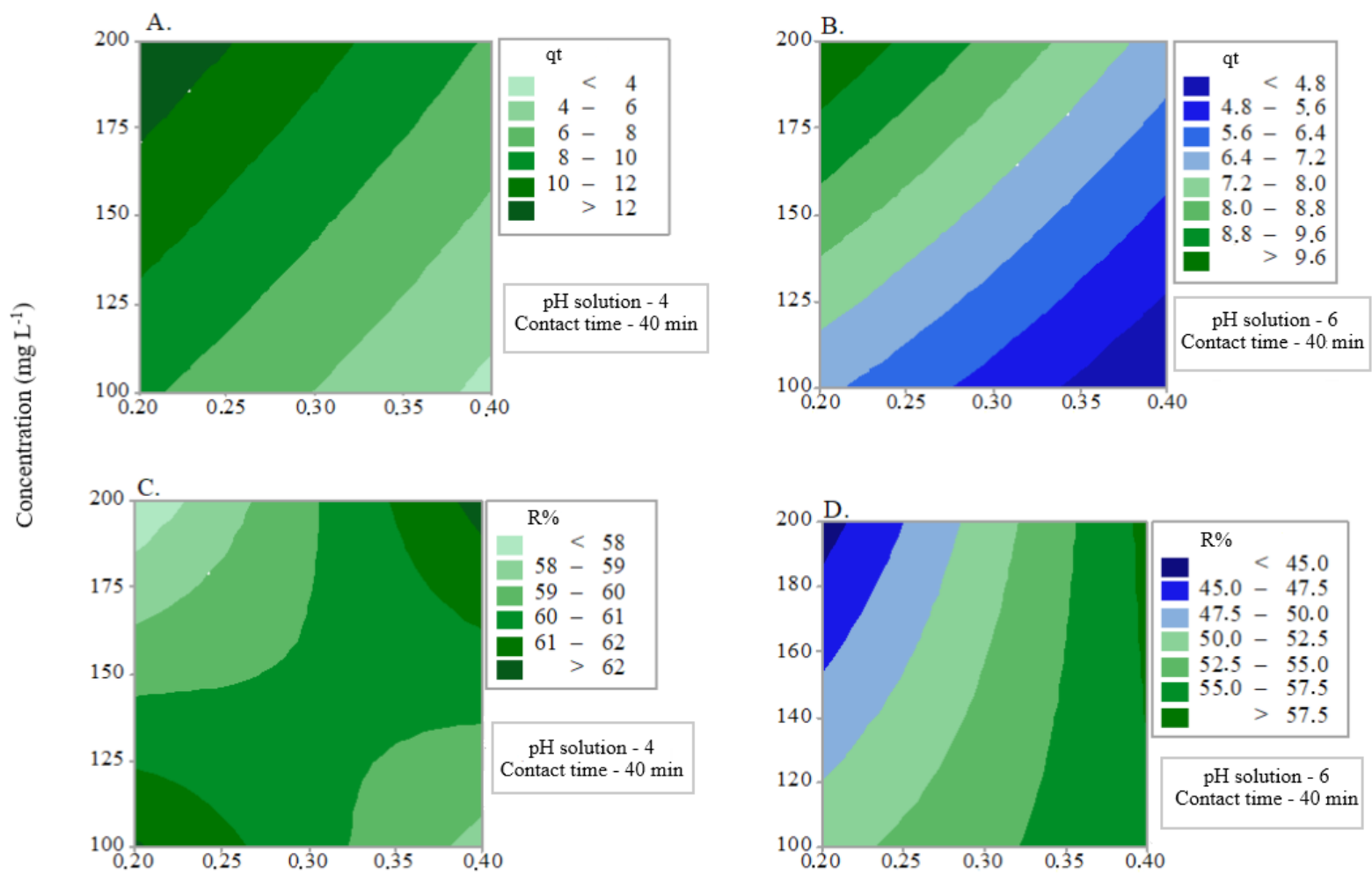

Mass of orange peels $(\mathrm{g})$

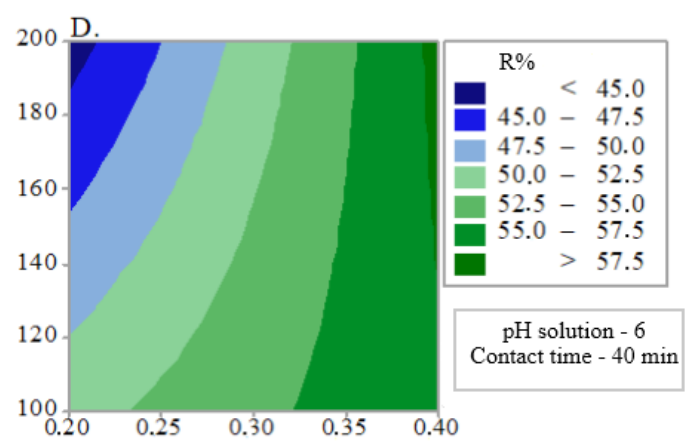

Figure 4. Contour plots for the mass of orange peels and dye initial concentration, at contact time of $40 \mathrm{~min}$ for the adsorbed quantity (qt) with $\mathrm{pH}$ solution of 4.0 (A) and with $\mathrm{pH}$ solution of $6.0(\mathrm{~B})$; and for the removal percentage ( $\mathrm{R} \%)$ with $\mathrm{pH}$ solution of 4.0 (C) and with $\mathrm{pH}$ solution of 6.0 (D)

\section{Conclusions}

1. The two-term exponential model is the most appropriate to describe the drying of orange peel at temperatures of 60 and $80^{\circ} \mathrm{C}$.

2. The biosorbent made from orange peel proves to be efficient for removing burgundy-16 dye, being able to remove more than $60 \%$ of the dye load at $40 \mathrm{~min}$.

\section{Literature Cited}

ABIT - Associação Brasileira da Indústria Têxtil e de Confecção. Cartilha indústria têxtil e de confecção brasileira. Brasília: ABIT, 2013. 44p.

Asfaram, A.; Fathi, M. R.; Khodadoust, S.; Naraki, M. Removal of direct red $12 \mathrm{~B}$ by garlic peel as a cheap adsorbent: Kinetics, thermodynamic and equilibrium isotherms study of removal. Spectrochimica Acta Part A: Molecular and Biomolecular Spectroscopy, v.127, p.415-421, 2014. https://doi.org/10.1016/j. saa.2014.02.092
Barrios-Ziolo, L. F.; Gaviria-Restrepo, L. F.; Agudelo, E. A.; CardonaGallo, S. A. Technologies for the removal of dyes and pigments present in wastewater: A review. Revista de Ingeniería Dyna, v.82, p.118-126, 2015. https://doi.org/10.15446/dyna.v82n191.42924

Barros Neto, B. de; Scarminio, I. S.; Bruns, R. E. Como fazer experimentos: Pesquisa e desenvolvimento na ciência e na indústria. Campinas: UNICAMP, 2001. 401p.

Boas, N. V.; Casarin, J.; Caetano, J.; Gonçalves Junior, A. C.; Tarley, C. R. T.; Dragunski, D. C. Biossorção de cobre utilizando-se o mesocarpo e o endocarpo da macadâmia natural e quimicamente tratados. Revista Brasileira de Engenharia Agrícola e Ambiental, v.16, p.1359-1366, 2012. https://doi.org/10.1590/S141543662012001200014

Corrêa Filho, L. C.; Martinazzo, A. P.; Teodoro, C. E. de S.; Andrade, E. T. de. Post-harvest of parsley leaves (Petroselinum crispum): Mathematical modelling of drying and sorption processes. Revista Brasileira de Engenharia Agrícola e Ambiental, v.22, p.131-136, 2018. https://doi.org/10.1590/1807-1929/agriambi. v22n2p131-136 
Cypriano, D. Z.; Silva, L. L. da; Mariño, M. A.; Tasic, L. A biomassa da laranja e seus subprodutos. Revista Virtual de Química, v.9, p.176-191, 2017. https://doi.org/10.21577/1984-6835.20170014

Djilani, C.; Zaghdoudi, R.; Modarressi, A.; Rogalski, M.; Djazi, F.; Lallam, A. Elimination of organic micropollutants by adsorption on activated carbon prepared from agricultural waste. Chemical Engineering Journal, v.189, p.203-212, 2012. https://doi. org/10.1016/j.cej.2012.02.059

Feng, N.-C.; Guo, X.-Y.; Liang, S. Enhanced Cu (II) adsorption by orange peel modified with sodium hydroxide. Transactions of Nonferrous Metals Society of China, v.20, p.146-152, 2010. https:// doi.org/10.1016/S1003-6326(10)60030-1

Fiorentin, L. D.; Menon, B. T.; Alves, J. A.; Barros, S. T. D. de; Pereira, N. C.; Lima, O. C. da M.; Módenes, A. N. Análise da secagem do bagaço de laranja em camada fina utilizando modelos semiteóricos e empíricos. Engevista, v.14, p.22-33, 2012. https://doi. org/10.22409/engevista.v14i1.294

Fiorentin, L. D.; Módenes, A. N.; Espinoza-Quiñones, F. R.; Trigueros, D. E. G.; Kroumov, A. D.; Manenti, D. R.; Borba, C. E. Biosorption of the reactive blue $5 \mathrm{G}$ dye in a fixed bed column packed with orange bagasse: Experimental and mathematical modelling. Separation Science and Technology, v.50, p.2267-2275, 2015. https://doi.org/10.1080/01496395.2015.1047453

Gnanasambandam, R.; Proctor, A. Determination of pectin degree of esterification by diffuse reflectance Fourier transform infrared spectroscopy. Food Chemistry, v.68, p.327-332, 2000. https://doi. org/10.1016/S0308-8146(99)00191-0

Guiza, S. Biosorption of heavy metal from aqueous solution using cellulosic waste orange peel. Ecological Engineering, v.99, p.134140, 2017. https://doi.org/10.1016/j.ecoleng.2016.11.043

Holanda, C. A.; Teixeira, T. M. V.; Souza, J. L.; Silva, H. A. S.; Santana, S. A. A.; Bezerra, C. W. B.; Farias, R. F. Babaçu como biossorvente de baixo custo para a remoção do azul remazol e do vermelho remazol. Química dos Materiais, v.2, p.15-24, 2012.

Khaled, A.; Nemr, A. E.; El-Sikaily, A.; Abdelwahab, O. Treatment of artificial textile dye effluent containing direct yellow 12 by orange peel carbon. Desalination, v.238, p.210-232, 2009. https://doi. org/10.1016/j.desal.2008.02.014

Mafra, M. R.; Igarashi-Mafra, L.; Zuim, D. R.; Vasques, E. C.; Ferreira, M. A. Adsorption of remazol brilliant blue on an orange peel adsorbent. Brazilian Journal of Chemical Engineering, v.30, p.657665, 2013. https://doi.org/10.1590/S0104-66322013000300022
Mostafa, M. Waste water treatment in textile industries: The concept and current removal technologies. Journal of Biodiversity and Environmental Sciences, v.7, p.501-525, 2015.

Nascimento, G. E. do; Duarte, M. M. M. B.; Campos, N. F.; Barbosa, C. M. de B. M.; Silva, V. L. da. Adsorption of the reactive gray BF-2R dye on orange peel: Kinetics and equilibrium studies. Desalination and Water Treatment, v.52, p.1578-1588, 2014. https://doi.org/10 $.1080 / 19443994.2013 .788457$

Noreen, S.; Bhatti, H. N.; Nausheen, S.; Sadaf, S.; Ashfaq, M. Batch and fixed bed adsorption study for the removal of Drimarine Black CL-B dye from aqueous solution using a lignocellulosic waste: A cost affective adsorbent. Industrial Crops and Products, v.50, p.568-579, 2013. https://doi.org/10.1016/j.indcrop.2013.07.065

Pavan, F. A.; Gushikem, Y.; Mazzocato, A. C.; Dias, S. L. P.; Lima, E. C. Statistical design of experiments as a tool for optimizing the batch conditions to methylene blue biosorption on yellow passion fruit and mandarin peels. Dyes and Pigments, v.72, p.256-266, 2007. https://doi.org/10.1016/j.dyepig.2005.09.001

Rehman, M. S. U.; Kim, I.; Han, J.-I. Adsorption of methylene blue dye from aqueous solution by sugar extracted spent rice biomass. Carbohydrate Polymers, v.90, p.1314-1322, 2012. https://doi. org/10.1016/j.carbpol.2012.06.078

Safa, Y.; Bhatti, H. N. Kinetic and thermodynamic modeling for the removal of direct red-31 and direct orange-26 dyes from aqueous solutions by rice husk. Desalination, v.272, p.313-322, 2011. https://doi.org/10.1016/j.desal.2011.01.040

Santhi, T.; Manonmani, S.; Vasantha, V. S.; Chang, Y. T. A new alternative adsorbent for the removal of cationic dyes from aqueous solution. Arabian Journal of Chemistry, v.9, p.466-474, 2016. https://doi.org/10.1016/j.arabjc.2011.06.004

Santos, C. M.; Morais, L. C. de. Parâmetros termodinâmicos da casca de laranja desidratada. Química Nova, v.38, p.488-492, 2015.

Santos, F. S. dos; Figueirêdo, R. M. F. de; Queiroz, A. J. de M.; Santos, D. da C. Drying kinetics and physical and chemical characterization of white-fleshed 'pitaya' peels. Revista Brasileira de Engenharia Agrícola e Ambiental, v.21, p.872-877, 2017. https://doi. org/10.1590/1807-1929/agriambi.v21n12p872-877

Tamer, C.; Isci, A.; Kutlu, N.; Sakiyan, O.; Sahin, S.; Sumnu, G. Effect of drying on porous characteristics of orange peel. International Journal of Food Engineering, v.12, p.921-928, 2016. https://doi. org/10.1515/ijfe-2016-0075 